\title{
Single-dose oral treatment of gonorrhoea in men and women, using ampicillin alone and combined with probenecid
}

\author{
ANNE BRO-JØRGENSEN AND TAGE JENSEN \\ Municipal Clinic of Venereal Diseases, Copenhagen, Denmark
}

In Scandinavia, as in many other Western countries, there has been an alarming rise in the incidence of gonorrhoea: the number of cases registered in Copenhagen has almost doubled over the past 4 years.

This large increase in infections has not corresponded with a rise in the proportion of gonococcal strains with reduced sensitivity to penicillin, which has remained unchanged at about 30 per cent. for several years. Nor has there been an increase in the proportion of gonococcal strains with strongly reduced susceptibility to penicillin. Accordingly, the rising incidence of infections is unlikely to be due to increasing failure of treatment with penicillin. In seeking other causes, the wide use of the contraceptive pill and the diminishing use of condoms, the considerable rise in promiscuity, and a growing number of cases of asymptomatic gonococcal urethritis in males, all appear to be relevant.

In this context we considered it opportune to devise a method of treatment which would be more acceptable to the patient, and which would reduce the work-load in a busy clinic.

Oral medication seemed preferable and we considered single-dose treatment as essential in the management of patients in a metropolitan clinic. The earlier oral penicillins had proved unsatisfactory when administered in this manner but ampicillin appeared to offer possibilities of success. This semi-synthetic penicillin is acid-stable, and is well-absorbed when taken by mouth. Compared with penicillin, a smaller proportion becomes bound to the plasma proteins so that higher tissue concentrations are obtained at the sites of infection (Kunin, 1966).

In addition, ampicillin has been demonstrated in vitro to have a greater bactericidal effect than penicillin $G$ against gonococcal strains with decreased sensitivity to penicillin (Ödegaard, 1962). When we changed over to treating gonorrhoea with oral ampicillin in 1967, the few published reports on this type of therapy mostly lacked information on the

Received for publication May 11, 1971

Address for reprints: Tietgensgade 31, Copenhagen, Denmark penicillin sensitivity of the gonococcal strains (Alergant, 1963; Marmell, Sills, Brown, and Prigot, 1964; Willcox, 1963, 1964), and presented varying results derived from small numbers of cases. The best results appeared to have followed treatment with ampicillin given in divided doses, a finding recently corroborated by Groth and Hallqvist (1970).

In the trial to be described we aimed at finding the most effective single oral dose of ampicillin and in order to reinforce its effect we combined ampicillin with probenecid to produce a higher blood level and a longer duration of ampicillinaemia (Tuano, Johnsone Brodie, and Kirby, 1966). Gundersen, Ödegaard, and Gjessing (1969) reported excellent results with this combination, namely a failure rate of only 1.4 per cent. of 437 cases in men.

\section{Material and methods}

MATERIAL

The trial was carried out in a public clinic for venereal diseases in the centre of Copenhagen, and involved 1,915 men and 921 women, who were treated for uncomplicated gonorrhoea from mid-1967 to mid-1970.

\section{DIAGNOSIS}

This was made initially by demonstration of intracellular diplococci in a methylene blue stained smear of secretions from the urethra in men and from the urethra and/or cervix in women. At the same time, specimens were taken for culture from all patients: in the male group from the urethra, and also from the rectum if homosexuality was suspected; in the female group samples were taken from the urethra, cervix, and rectum. Only those cases in which positive cultures were obtained are included in this series.

The cultures were carried out in the Neisseria Division of the Statens Seruminstitut, Copenhagen. Using the plate dilution method with 4-fold dilution steps, the sensitivity of the gonococci to penicillin $\mathrm{G}$ was determined (Reyn, Bentzon, and Ericsson, 1963), and the results expressed as the 50 per cent. inhibitory concentration in $\mu \mathrm{g} . / \mathrm{ml}$. penicillin $\mathrm{G}\left(\mathrm{IC}_{50}\right)$. The strains were divided into two groups, denoted fully sensitive $\left(\mathrm{IC}_{50} \leqslant 0.038 \mu \mathrm{g} . / \mathrm{ml}\right.$.) and less sensitive $\left(\mathrm{IC}_{50} \geqslant 0.053 \mu \mathrm{g} . / \mathrm{ml}\right.$. penicillin $\left.\mathrm{G}\right)$.

TREATMENT

Four successive series of patients were given a single oral dose; ampicillin 1 g., ampicillin 2 g. (Doctacillin (B) 
Astra), and the same doses combined with 1 g. probenecid (Probecid (B) Astra) respectively. The tablets were taken in the clinic under the physician's direct supervision.

Those patients who gave a history of allergy to penicillin were treated differently and excluded from the series.

\section{FOLLOW-UP}

The aim was to obtain negative result to three cultures before the patient was considered cured. In order to deal promptly with recurrences, the patients were asked to attend the clinic for follow-up at 2- to 4-day intervals, so that the third culture was taken not less than 8 days after treatment. The patients were told to avoid sexual intercourse until they were declared cured, and information concerning the relevant legal provisions was given. Those who neglected to come for re-examination were reminded by a letter, and in a few cases it was necessary to request the cooperation of the police in order to bring the patients to attend the clinic (treatment of venereal disease is legally enforced in Denmark).

75 per cent. of the patients came to three follow-up examinations, 17 per cent. to two, and 8 per cent. to only one. The follow-up tests were completed for 17 per cent. of the patients in less than 8 days after treatment, for a further 38 per cent. during the second week, and for 45 per cent. after more than 2 weeks. In addition, there was a final interview with the majority of patients, when the result of the third culture was known approximately 1 week after the last attendance. Patients who failed to attend for at least one follow-up examination are excluded from the series.

\section{TREATMENT FAILURE AND RE-INFECTION}

Those cases from which a positive culture was obtained during the follow-up period within 4 weeks after treatment were classified as follows:

\section{Failures}

We have considered as failures of treatment those cases in which positive cultures were obtained within 14 days after treatment, regardless of previous negative cultures during the first week, on the grounds that treatment could have temporarily reduced the bacteria to such an extent that the few remaining gonococci were not detectable by culture.

\section{Re-infections}

The remaininz cases were classified as re-infections. In some cases re-infection was also indicated by differences in the sensitivity to penicillin of the strains isolated before and after treatment. If this difference was 4-fold or more, it was unlikely that the strain could be the same as that initially cultured from the patient (Reyn and Bentzon, 1963). Finally, we assigned as re-infections those cases in which a renewed sexual contact with an infected untreated partner was admitted.

\section{Results}

PENICILLIN SENSITIVITY OF THE GONOCOCCI

The Figure shows that the patterns of sensitivity to penicillin of the gonococcal strains isolated during the four periods of treatment remained so similar that a direct comparison between the results of treatment was possible.

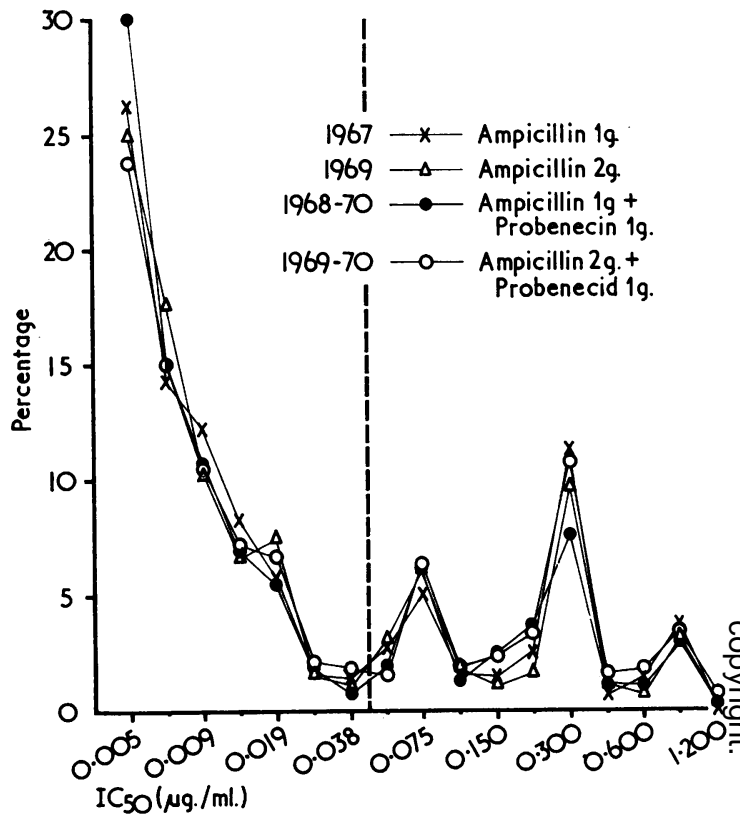

FIGURE Penicillin sensitivity of gonococcal strains in the four treatment groups

The number of strains with reduced sensitivity to penicillin for each treatment group is recorded in Table I. The overall proportion of less sensitive strains for males was 33 per cent., and for females 27 per cent. The differences between the froportions among the sexes in the individual groups could be regarded as irrelevant, but the difference between the overall proportion for men and women is significant $(\mathbf{P}<0.01)$. We are unable to suggest a reasonable explanation for this finding.

\section{RESULTS OF TREATMENT \\ Males}

Table I shows that treatment of men with $1 \mathrm{~g}$. ampicillin resulted in failure in 10.6 per cent. of cases, and with $2 \mathrm{~g}$. in 6.5 per cent. Only when $1 \mathrm{~g}$. probenecid was added to these doses did the failure rate fall to 1.9 per cent., irrespective of the ampicillin dose, a significantly better result than that obtained by ampicillin alone $(P<0.01)$. Failures of treatment were found to occur predominantly among patients infected with strains with a reduced sensitivity to penicillin. When the patients were treated with 1 or 
I A B L E I Results of oral single-dose treatment of gonorrhoea by ampicillin alone and in combination with probenecid. Failure of treatment related to penicillin sensitivity of gonococcal strains

\begin{tabular}{|c|c|c|c|c|c|c|c|c|c|c|c|c|c|}
\hline \multirow[t]{3}{*}{ Sex } & \multicolumn{2}{|l|}{ Treatment } & \multicolumn{5}{|c|}{ All patients } & \multicolumn{3}{|c|}{$\begin{array}{l}\text { Patients infected with } \\
\text { sensitive strains } \\
\left(I C_{50}: \leqslant 0.0047-\right. \\
0.038 \mu \mathrm{g} . / \mathrm{ml} .)\end{array}$} & \multicolumn{3}{|c|}{$\begin{array}{l}\text { Patients infected with } \\
\text { less sensitive strains } \\
\left(I C_{50}: \geqslant 0.053-\geqslant 1.2\right. \\
\mu \mathrm{g} . / \mathrm{ml} .)\end{array}$} \\
\hline & \multirow{2}{*}{ Drug } & \multirow{2}{*}{ Dose (g.) } & \multirow{2}{*}{ Total } & \multicolumn{2}{|c|}{$\begin{array}{l}\text { Failures of } \\
\text { Treatment }\end{array}$} & \multicolumn{2}{|c|}{ Re-infections } & \multirow{2}{*}{ Total } & \multicolumn{2}{|c|}{$\begin{array}{l}\text { Failures of } \\
\text { Treatment }\end{array}$} & \multirow{2}{*}{ Total } & \multicolumn{2}{|c|}{$\begin{array}{l}\text { Failures of } \\
\text { Treatment }\end{array}$} \\
\hline & & & & No. & $\begin{array}{l}\text { Per } \\
\text { cent. }\end{array}$ & No. & $\begin{array}{l}\text { Per } \\
\text { cent. }\end{array}$ & & No. & $\begin{array}{l}\text { Per } \\
\text { cent. }\end{array}$ & & No. & $\begin{array}{l}\text { Per } \\
\text { cent. }\end{array}$ \\
\hline \multirow[t]{4}{*}{ Males } & Ampicillin & 1 & 161 & 17 & 10.6 & 6 & $3 \cdot 7$ & 111 & 3 & $2 \cdot 7$ & 50 & 14 & 28 \\
\hline & Ampicillin & 2 & 336 & 22 & 6.5 & 6 & $1 \cdot 8$ & 230 & 7 & $3 \cdot 0$ & 106 & 15 & $14 \cdot 2$ \\
\hline & $\begin{array}{l}\text { Ampicillin } \\
\text { + Probenecid }\end{array}$ & $\begin{array}{l}1 \\
1\end{array}$ & 617 & 12 & $1 \cdot 9$ & 11 & $1 \cdot 8$ & 431 & 3 & 0.7 & 186 & 9 & $4 \cdot 8$ \\
\hline & $\begin{array}{l}\text { Ampicillin } \\
\text { + Probenecid }\end{array}$ & $\begin{array}{l}2 \\
1\end{array}$ & 801 & 15 & $1 \cdot 9$ & 32 & $4 \cdot 0$ & 505 & 5 & $1 \cdot 0$ & 296 & 10 & $3 \cdot 4$ \\
\hline \multirow[t]{4}{*}{ Females } & Ampicillin & 1 & 79 & 3 & $3 \cdot 8$ & 1 & $1 \cdot 3$ & 56 & 2 & $3 \cdot 6$ & 23 & 1 & $4 \cdot 3$ \\
\hline & Ampicillin & 2 & 146 & 4 & $2 \cdot 7$ & 4 & $2 \cdot 7$ & 110 & 2 & $1 \cdot 8$ & 36 & 2 & $5 \cdot 6$ \\
\hline & $\begin{array}{l}\text { Ampicillin } \\
+ \text { Probenecid }\end{array}$ & $\begin{array}{l}1 \\
1\end{array}$ & 303 & 7 & $2 \cdot 3$ & 11 & $3 \cdot 7$ & 224 & 1 & 0.4 & 79 & 6 & $7 \cdot 6$ \\
\hline & $\begin{array}{l}\text { Ampicillin } \\
+ \text { Probenecid }\end{array}$ & $\begin{array}{l}2 \\
1\end{array}$ & 393 & 9 & $2 \cdot 3$ & 9 & $2 \cdot 3$ & 290 & 6 & $2 \cdot 1$ & 103 & 3 & 2.9 \\
\hline
\end{tabular}

2 g. ampicillin alone, the failure rates in cases of infection with less sensitive strains were 28 and 14 per cent. respectively, while the addition of probenecid to these doses reduced the failure rates to 4.8 and 3.4 per cent. which represents a significant improvement $(P<0.01)$.

\section{Females}

Here the failure rates were low in all four treatment groups (2.3 to 3.8 per cent.). The differences between the groups are not significant, even on comparison of failure rates in those infected by strains with reduced sensitivity to penicillin.

For infections caused by strains fully sensitive to penicillin, the failure rates were low in both males and females, regardless of the treatment. No statistic ally significant differences could be found between the individual treatment groups. However, if the groups treated with ampicillin alone were added and compared with the ampicillin-probenecid groups likewise added, a significantly better result was obtained with the combined treatment.

RECTAL GONORRHOEA IN FEMALES (Table II)

Gonococci were cultured from the rectum in 326 (35.4 per cent.) of the 921 females.

The rectal infection was usually symptomless and accompanied by urogenital infection; in 4 per cent. of the cases gonococci were isolated from the rectum only. It has been suggested (Hagerman, 1948; Scott

T A B LE II Results of treatment of gonorrhoea in females with positive or negative cultures from rectum

Treatment

\begin{tabular}{ll}
\hline Drug & Dose (g.) \\
\hline Ampicillin & 1 \\
Ampicillin & 2 \\
Ampicillin & 1 \\
+ Probenecid & 1 \\
Ampicillin & 2 \\
+ Probenecid & 1 \\
\hline Total &
\end{tabular}

Culture of $\mathbf{N}$. gonorrhoeae from rectum

\begin{tabular}{|c|c|c|c|c|c|c|c|}
\hline \multicolumn{4}{|c|}{ Positive } & \multicolumn{4}{|c|}{ Negative } \\
\hline \multirow{2}{*}{ Total } & \multicolumn{2}{|c|}{$\begin{array}{l}\text { Failures of } \\
\text { treatment }\end{array}$} & \multirow{2}{*}{ Re-infections } & \multirow{2}{*}{ Total } & \multicolumn{2}{|c|}{$\begin{array}{l}\text { Failures of } \\
\text { treatment }\end{array}$} & \multirow{2}{*}{ Re-infections } \\
\hline & No. & Per cent. & & & No. & Per cent. & \\
\hline 40 & 1 & 2.5 & 1 & 39 & 2 & $5 \cdot 1$ & 0 \\
\hline 52 & 2 & $3 \cdot 8$ & 1 & 94 & 2 & $2 \cdot 1$ & 3 \\
\hline 113 & 3 & $2 \cdot 7$ & 4 & 190 & 4 & $2 \cdot 1$ & 7 \\
\hline 121 & 4 & $3 \cdot 3$ & 4 & 272 & 5 & $1 \cdot 8$ & 5 \\
\hline 326 & 10 & 3 & 10 & 595 & 13 & $2 \cdot 2$ & 15 \\
\hline
\end{tabular}


and Stone, 1966) that the presence of penicillinaseproducing organisms in the rectum might destroy penicillin and thus protect the gonococci against the bactericidal effect of this antibiotic, but this is not supported by an earlier investigation of one of the authors (Jensen, 1953).

Table II compares failures of treatment in rectal and non-rectal infections.

If we consider the four treatment groups added together, there was a 3 per cent. failure rate in the cases in which the rectum was infected and one of 2 per cent. in the non-rectal infections. This difference is not statistically significant.

\section{RE-TREATMENT IN CASES OF FAILURE AND RE-INFECTION (Table III)}

39 cases of treatment failure and 61 of re-infection, from the combined therapy groups and the group treated with $2 \mathrm{~g}$. ampicillin, were re-treated by the same method used in initial treatment. Surprisingly, the overall cure rate for the 39 cases of initial failure was approximately 84 per cent.

\section{SIDE-EFFECTS}

It is well known that ampicillin may cause exanthemata, although it has been claimed that there is a great difference in this respect between the various ampicillin preparations. In none of our cases, including those re-treated, were side-effects observed, possibly because of the relatively short duration of the ampicillinaemia. As previously mentioned, patients suspected of being allergic to penicillin were treated with other agents and excluded from the study.

\section{Discussion}

No certain differential criteria for treatment failure and re-infection have been established, and the reappearance of gonococci after treatment is interpreted in different ways, making a comparison between the results of treatment obtained by different authors somewhat difficult. Attempts at strict classification of treatment failure or re-infection may lead to error, especially with regard to early reinfections which are liable to be recorded as failures of treatment. Thus, even with a theoretically 100 per cent. effective treatment, one can rarely prove it to be so in practice.

The results obtained by using a single dose of $1 \mathrm{~g}$. ampicillin in men were not satisfactory, only 90 per cent. being cured. This was due to a high failure rate in patients infected by less sensitive strains of gonococci. Not even doubling the dose led to an acceptable result. Only after the addition of probenecid was the cure rate increased to about 98 per cent.

Ampicillin $1 \mathrm{~g}$. plus probenecid will give about the same peak serum concentration as ampicillin $2 \mathrm{~g}$. and the better result with the former may be ascribed to the prolonged duration of effective ampicillinaemia.

Gundersen and others (1969) reported a cure rate of 98.6 per cent. in male cases of gonorrhoea treated with ampicillin $2 \mathrm{~g}$. and probenecid $1 \mathrm{~g}$., a result which is in full agreement with ours (98.1 per cent.) Groth and Hallqvist (1970) achieved a cure rate of $10 \Phi$ per cent. in treating male and female cases with ampicillin, but they used two doses of $1 \mathrm{~g}$. with 5-hour interval. Experience shows that some venereaT disease clinic patients cooperate poorly and one has misgivings about using this double-dose method, as there is no certainty that the patient will take the second dose at the proper time.

The result of re-treating the cases of failure by repeating the initial treatment was surprising. In each group there was the same high cure rate of about 85 per cent. A possible explanation for this result could be that some of those recorded as therapy failures after the initial treatment were actually cases of re-infection; if so, the cure rate for the initial treatment may be even better than we have recorded. At all events, the practical result is that the finding of

TA B L I I Results of re-treatment of cases of failure and re-infection by repeating the initial treatment (all patients)

\begin{tabular}{|c|c|c|c|c|c|c|c|c|c|}
\hline \multicolumn{2}{|l|}{ Treatment } & \multicolumn{4}{|c|}{ Re-treated failures } & \multicolumn{4}{|c|}{ Re-treated re-infections } \\
\hline Drug & Dose (g.) & Total & Gc.neg. & Failure & $R e$-infection & Tota & Gc.neg. & Failure & Re-infection \\
\hline Ampicillin & 2 & 14 & 11 & 2 & 1 & 10 & 8 & 0 & 2 \\
\hline $\begin{array}{l}\text { Ampicillin } \\
+ \text { Probenecid }\end{array}$ & $\begin{array}{l}1 \\
1\end{array}$ & 10 & 7 & 2 & 1 & 18 & 13 & 1 & 4 \\
\hline Total & & 39 & 31 & 6 & 2 & 61 & 51 & 2 & 8 \\
\hline
\end{tabular}


gonococci during the follow-up period after treatment with ampicillin plus probenecid does not indicate changing the treatment; repeating the initial treatment will usually lead to cure.

The advantages of the single oral dose of ampicillin plus probenecid are as follows:

(1) It is practical and simple, because probenecid and ampicillin are given simultaneously, whereas the use of probenecid in conjunction with a parenterallyadministered antibiotic is more laborious and timeconsuming.

(2) It is highly effective, the cure rate of approximately 98 per cent. being as good as the best results obtained by other methods.

(3) It is convenient for the patients and may encourage those frightened of injections to attend the clinic both for a first visit and for subsequent examinations.

(4) It ensures that the patient receives the correct dosage, and that the tablets are not kept for later use, or given to others.

\section{Summary}

An account is given of single-dose treatment of uncomplicated gonorrhoea in 1,915 males and 921 females with the oral administration of either $1 \mathrm{~g}$. or $2 \mathrm{~g}$. ampicillin alone, or the same combined with $1 \mathrm{~g}$. probenecid.

In about 30 per cent. of cases the infections were caused by gonococci with reduced sensitivity to penicillin $\left(\mathrm{IC}_{50} \geqslant 0.053 \mu \mathrm{g} . / \mathrm{ml}\right.$.). The best results were obtained by the combined treatment, the cure rates being $98 \cdot 1$ per cent. for males and 97.7 per cent. for females. There was no significant difference between the results obtained with the combined treatment, using either $1 \mathrm{~g}$. or $2 \mathrm{~g}$. ampicillin. Even for infections caused by less sensitive strains the cure rates were high; using $1 \mathrm{~g}$. or $2 \mathrm{~g}$. ampicillin plus probenecid the overall cure rates were 94.3 and 96.8 per cent. respectively.

In 37 per cent. of the cases in women, gonococci could be demonstrated in cultures from the rectum. The cure rate in these cases was identical with that found in patients harbouring gonococci in the urogenital tract only.

Cases of treatment failure in the groups receiving $2 \mathrm{~g}$. ampicillin alone, or 1 or $2 \mathrm{~g}$. ampicillin combined with probenecid, were re-treated with the initial drug therapy. By this re-treatment 85 per cent. were cured.

No side-effects from the treatment were observed.

The authors wish to thank Erik Iverson, Dansk Tuberkulose Index, for the statistical evaluation. Our thanks are also due to Astra Läkemedel AB, Södertälje, Sweden, for supplies of Doctacillin and Probenecid and for help in various ways.

\section{References}

Alergant, C. D. (1963) Brit. F. vener. Dis., 39, 225

Groth, O., and Hallqvist, L. (1970) Ibid., 46, 21

Gundersen, T., ÖdegaARd, K., and GJessing, H. C. (1969) Ibid., 45, 235

HAGERMAN, G. (1948) Acta derm.-veneresl. (Stockh.), 28, 362

Jensen, T. (1953) Brit. F. vener. Dis., 29, 222

Kunin, C. M. (1966) Clin. Pharmacol. Ther., 7, 166

Marmell, M., Sills, J. R., Brown, C. D., and Prigot, A. (1964) N.Y. St. F. Med., 64, 985

ÖDEGAARD, K. (1962) Brit. med. F., 1, 645

Reyn, A., and Bentzon, M. W. (1963) Acta derm.venereol. (Stockh.), 43, 394

,-- , and ERIcsson, H. (1963) Acta path. microbiol. Scand., 57, 235

Scott, J., and Stone, A. H. (1966) Brit. F. vener. Dis., 42, 103

Tuano, S. B., Johnson, L. D., Brodie, J. L., and Kirby, W. M. M. (1966) New Engl. F. med., 275, 635

WILlcox, R. R. (1963) Brit. F. vener. Dis., 39, 164

- (1964) Ibid., 40, 261

Traitement de la gonococcie masculine et féminine par une dose orale unique d'ampicilline combinée au probénécide

SOMMAIRE

On rend compte du traitement de la gonococcie non compliquée, chez 1.915 hommes et 921 femmes, par une dose unique orale de 1 ou $2 \mathrm{~g}$. d'ampicilline seule, ou des mêmes doses associées à $1 \mathrm{~g}$. de probénécide.

Dans environs 30 pour cent des cas, la maladie était due à des gonocoques ayant eu une sensibilité réduite à la penicilline $\left(\mathrm{CMI}_{50} \geqslant 0,053 \mathrm{\mu g}\right.$. $/ \mathrm{ml}$. $)$.

Les meilleurs résultats ont été obtenus avec le traitement combiné qui a donné un pourcentage de guérison de 98,1 chez les hommes et de 97,7 chez les femmes. Il n'y eut pas de difference significative dans les résultats obtenus avec le traitement combiné, que l'on donne 1 ou 2 g. d'ampicilline. Même pour les cas dûs à des souches moins sensibles, les taux de guérison furent élévés et, dans l'ensemble, l'association de 1 ou $2 \mathrm{~g}$. d'ampicilline + probénécide a donné, respectivement, des taux de guérison de 94,3 et 96,6 pour cent.

Dans 37 pour cent des cas féminins, le gonocoque put être trouvé par culture dans le rectum. Le taux de guérison de ces cas fut le même que pour les malades ne presentant de gonocoques que dans les voies urogénitales. Les cas n'ayant pas répondu au traitement dans les groupes recevant $2 \mathrm{~g}$. d'ampicilline seule, ou 1 ou $2 \mathrm{~g}$. d'ampicilline associée à $1 \mathrm{~g}$. de probénécide furent re-traités avec le même traitement que la première fois; 85 pour cent furent guéris. On n'observa aucun effet secondaire du traitement. 